\title{
Violência e crime em Luiz Alfredo Garcia-Roza: um misto de policial e
}

\author{
psicanálise
}

DOI: https://doi.org/10.22409/pragmatizes.v10i18.40251

\section{Fernanda Mara de Almeida Azevedo ${ }^{1}$}

Resumo: No presente artigo, pretende-se mostrar que o Romance policial contemporâneo na produção ficcional do brasileiro Luiz Alfredo Garcia-Roza (1936-) utiliza as técnicas da literatura policial para indicar os sintomas do mal-estar cultural que atinge o sujeito ficcional, transformando-o em verdadeiras subjetividades criminais - metáfora do indivíduo de hoje. Em suas narrativas situadas nos anos de 1990 até os dias atuais - o autor, num misto de literatura e psicanálise, considera que, em meio a uma sociedade culturalmente 'esquizofrênica', temáticas ligadas a crimes, mortes e outros tipos de violência, predominantes na América Latina no século XXI, encontram solo fértil em narrativas policiais da atualidade. Atentando para o cenário caótico e desajustado onde as tramas de Garcia-Roza se inserem, nosso corpus será constituído pelos romances $O$ silêncio da chuva (1996), e Espinosa sem saída (2006). Neste constructo discursivo em que o mundo aparece como palco, o detetive Espinosa - o protagonista de Garcia-Roza - emerge como uma das subjetividades literárias perdidas que não encontram respostas para os questionamentos, desconstruindo a noção de totalidade e infalibilidade do investigador das narrativas clássicas de enigma. Afinal, na visão do próprio romancista, a essência de todo crime constitui-se como algo irrevelável, impenetrável e inescrutável.

Palavras-chave: Violência; crime; medo; subjetividades criminais.

Violencia y crimen en Luiz Alfredo Garcia-Roza: una mezcla de lo policiaco y la psicoanálisis.

Resumen: En este artículo, pretendemos demostrar que la Novela Policiaca contemporánea en la producción ficcional del autor brasileño Luiz Alfredo Garcia-Roza (1936-) utiliza las técnicas de la literatura policiaca para señalar los síntomas del mal estar cultural que acomete el sujeto ficcional, transformándole en auténticas subjetividades criminales - metáfora del indivíduo de hoy en día. En sus narrativas - ubicadas en los años de 1990 hacia los días actuales - el autor, en una mezcla de literatura y psicoanálisis, considera que, en el medio de una sociedad culturalmente 'esquizofrénica', temas relacionados a crímenes, muertes y otras clases de violencia, predominantes en la Latinoamérica del siglo XXI, encuentran una atmósfera propicia en narrativas policiacas de la actualidad. Cogitando sobre el contexto caótico y desordenado, donde se encierran las tramas de Garcia-Roza, nuestro corpus se compondrá de las siguientes novelas: O silêncio da chuva (1996) y Espinosa sem saída (2006). En esta construcción discursiva, en la que el mundo consiste en escenario, el detective Espinosa - el protagonista de Garcia-Roza - se manifiesta como una de las subjetividades literarias perdidas que no obtienen respuestas para las indagaciones, descontruyendo la noción de totalidad y infalibilidad del investigador de las narrativas clásicas de enigma. Al fin, según

\footnotetext{
${ }^{1}$ Fernanda Mara de Almeida Azevedo. Doutora em Literatura Comparada pela UERJ. Professora da Universidade de Vassouras, Campus Maricá, Brasil. E-mail: nandaspar@yahoo.com.br
}

Texto recebido em 30/12/2019 e aceito para publicação em 07/01/2020. 
la visión del propio novelista, la esencia de cualquier crimen se define como algo insondable, impenetrable y inescrutable.

Palabras clave: Violencia; crimen; miedo; subjetividades criminales.

Violence and Crime in Garcia-Roza: psychoanalytical detective story

\begin{abstract}
In this article, I expect to point out how Garcia-Roza, in his contemporarily approach to the detective-story genre, shows how cultural malaises can affect the fictional subject's psyche, switching them into real criminal subjectivities as a metaphorical representation to the contemporary individual. In his narratives set from 1990's onwards, by intermingling literature with psychoanalysis, the author claims that, in a culturally 'schizophrenic' society, themes like crime, death and other forms of violence predominate in the $21^{\text {st }}$-century Latin America, featuring as a prolific subject-matter in (and for) contemporary detective stories. By critically observing Garcia Roza's disordered and chaotic atmospheres, in this text, I highlight his novels O silêncio da chuva (1996) and Espinosa sem saída (2006) in which his protagonist detective Espinosa is carefully built as a culturally lost literary persona who allows the author to de-construct the investigator's total infallibility typically found in classic enigma narratives, providing that the character's never-ending perusals are constantly left unanswered. After all, as the novelist clarifies, the essence of every crime consists of something unveiled, impenetrable, inscrutable.
\end{abstract}

Keywords: Violence; crime; fear; criminal subjectivities.

\title{
Violência e crime em Luiz Alfredo Garcia-Roza: um misto de policial e psicanálise
}

A ideia do mal como algo inerente à estrutura social é muito forte nas narrativas criminais latinoamericanas, debilitadas por golpes e ditaduras militares ao longo da história.Pesquisas recentes mostram que A América Latina concentra $39 \%$ dos homicídios, e que, em menos de duas décadas, tornou-se a região mais violenta do planeta, registrando 2,5 milhões de homicídios, sendo $75 \%$ cometidos com arma de fogo.A pouca confiança nas instituições é outro fator relevante, sendo, por isso, de extrema urgência a criação de instituições eficientes, através da profissionalização das polícias e a sua consequente aproximação dos cidadãos.De acordo com a socióloga Maria Stela Grossi Porto (1999), estamos mergulhados em um social heterogêneo, no qual nem indivíduos nem grupos parecem reconhecer valores coletivos. No início do século $X X I$, a violência configura-se de diferentes formas: através das metamorfoses do crime, da crise das 
instituições de controle social e dos conflitos sociais.

O Brasil é apontado pela ONU como o segundo país mais violento da América do Sul em relação às altas taxas de homicídio intencional no mundo - ficando atrás apenas da Venezuela, com 30,5 mortes acima da média regional. Esse contexto dá origem a múltiplos arranjos societários e diferentes lógicas de conduta e permite que renomados escritores como Luiz Alfredo Garcia-Roza explore em sua ficção temas que atravessam não só o discurso literário: mas também o psicanalítico, o sociológico, 0 histórico, 0 antropológico.Em meio a uma sociedade culturalmente 'esquizofrênica', conforme assinala Fredric Jameson (1997), temáticas ligadas a crimes, mortes e outros tipos de violência encontram solo fértil em narrativas policiais como $O$ silêncio da chuva, romance de estreia do autor publicado em 1996 - e Espinosa sem saída (2006), que constituem o corpus do presente artigo.Segundo Therezinha Barbieri (2003), o romance policial atende à emergência deste

\footnotetext{
${ }^{2}$ Algumas noções como esquizofrenia cultural (segundo Jameson) e temas ligados ao discurso psicanalítico serão discutidos ao longo deste artigo.
}

novo contexto sociocultural, caracterizando-se como uma prosa em vitrine, na qual figuram personagens sem fundo, sem identidades definidas, onde se torna difícil para detetives como Espinosa - protagonista das tramas de Garcia-Roza - juntar os pedaços das informações ou reconstituir os fios narrativos.É importante ressaltar que, no contexto da ficção de Garcia-Roza, a esquizofrenia vai além de problema clínico. Sendo assim, propomo-nos a estudar a emergência do crime enquanto doença que atinge a sociedade, e cuja impossibilidade de decifração pode estar relacionada ao caráter de esquizofrenia cultural a que Jameson se refere.

Para discutir essa ideia, recorremos às reflexões de Wolfgang Iser (1996,) segundo o qual o acesso à realidade, na pós-modernidade, dá-se através de versões falsas e modos falsificados que amplificam a aparência da representação. A começar pelo mascaramento da lei, da polícia e das autoridades de maneira geral. Isto nos permite traçar relações importantes entre o gênero policial e o discurso psicanalítico, visto que o cenário contemporâneo desponta 
como um ambiente caótico, sombrio e inseguro; e onde as relações de controle da máquina estatal fomentam doenças - sejam neurológicas, físicas ou psíquicas.

As duas modalidades discursivas exercitam a suspeita, partindo de uma recusa ao óbvio. Por isso, interstícios tais como falhas, fendas, fragmentos e hesitações devem ser explorados pelo detetiveanalista para se alcançar o recôndito, o traumático, o doentio, o fobíaco, o violento e o macabro - traços do ld onde jaz o imaginário na ficção de Garcia-Roza. Para ampliar tal análise, traremos à tona a contribuição de teóricos como Michel Foucault, Sigmund Freud e Félix Guattari, que apontam para a força do capitalismo e para as falcatruas institucionais, vistas simbolicamente como um dos grandes 'monstros' da contemporaneidade. Gerando conflitos e instabilidade nos personagens de $O$ silêncio da chuva e Espinosa sem saída, a mistura entre policial e psicanálise corrobora a ideia de que, nas narrativas em análise, os detetives despontam como subjetividades perdidas, e precisam alcançar os desajustes psíquicos de criminosos que vão desde os fóbicos sociais até os psicopatas, assassinos, prostitutas e deslocados.A prosa ficcional de Garcia-Roza, situada nos anos de 1990, apresenta traços configuradores de um momento com fisionomia própria. Além de desconstruir preconceitos com a chamada baixa literatura (ou subliteratura), a qual o policial estaria inserido, sua narrativa estabelece relação com outros textos, faz referências cruzadas, intra e intertextuais.

A recorrência de índices metaficcionais denuncia a presença do literário a toda hora invadindo o nível de elaboração ficcional, o que constitui uma constante bem característica do período em questão (BARBIERI, 2003, p. 15). Segundo a autora, os anos de 1980 e 1990 se caracterizam pela livre coexistência das diferenças, das contradições, não só entre as obras, mas até no interior de uma mesma narrativa.Algumas marcas destas duas décadas são relevantes para a compreensão dos romances policiais de Garcia-Roza, a começar pela influência que recebe de autores ligados à tradição do gênero: Edgar Allan Poe e Conan Doyle, ícones dos romances clássicos de enigma; e dos 
criadores do roman noir: Dashiell Hammett e Raymond Chandler. A referência direta a estes nomes aponta não só para os índices metaficcionais a que Barbieri se refere, mas também para as contradições e diferenças no interior do discurso policialesco, começando pelo detetive, cercado de dúvidas acerca do mundo onde vive e da sua própria identidade, que se diferencia de Dupin, o primeiro detetive que compõe a tradição literária.

Nas três primeiras narrativas clássicas de Poe, os crimes permanecem insolúveis pela polícia parisiense até a intervenção voluntária do decifrador de enigmas. O herói se vale tão somente de sua atenção, de sua perspicácia e de seu raciocínio lógico para restabelecer a ordem e a lei, solucionando crimes que acontecem dentro da alta sociedade que ele próprio frequenta. Embora o investigador não seja um detetive profissional nem tampouco um policial, os exercícios lógico-dedutivos são facilitados pelas boas relações que ele mantém com seus informantes. 0 romance policial de enigma valoriza a onipotência do pensamento e a lógica imbatível dos personagens encarregados de proteger a vida burguesa. No entanto, esse modelo detetivesco só é possível em uma sociedade onde as fronteiras entre ordem e desordem, certo e errado, lei e crime apresentam-se bem definidas, como a sociedade inglesa do século XIX. Essas dicotomias possibilitam uma maior visualização de uma lei que precisa ser protegida contra tentativas de corrompê-la. O estudioso Ricardo Piglia explica que as regas do policial clássico se afirmam, sobretudo, no fetiche da inteligência pura, e por isso, o investigador desponta como 0 raciocinador puro, "o grande racionalista que defende a lei e decifra os enigmas" (PIGLIA, 1994, p. 78).

Em "Os crimes da Rua Morgue"3 Dupin assegura-nos de que não havia perdido a pista nem por um instante: "Não havia falha em nenhum elo de minha cadeia de raciocínio. (...). Meu alvo final é somente a verdade" (CRM, p. 128).As narrativas clássicas de enigma foram criadas para um tipo especial de leitor - o de histórias policiais - que sente prazer em acompanhar mistérios sempre

\footnotetext{
${ }^{3}$ POE, Edgar Allan. Os crimes da Rua Morgue. In: Histórias extraordinárias [Tales of the Grotesque and Arabesque (1840)]. Trad. Breno Silveira e outros. São Paulo: Abril Cultural, 1978. Todas as citações do conto pertencem a esta edição e serão indicadas pela sigla $C R M$, seguida do número da página.
} 
desvendados por obra da inteligência, por uma operação intelectual. Na visão de Jorge Luis Borges (1997), o detetive que segue esta tradição policial é sempre um homem muito inteligente "chamado Dupin, que depois se chamará Sherlock Holmes, que se chamará mais tarde Hercule Poirot, que terá outros nomes decerto famosos" (BORGES, 1997, p. 68). O método de criação do texto literário tem a ver com o pensamento da época: o Positivismo - daí a substituição da intuição pela presença da precisão e do rigor lógico no discurso ficcional.A evolução do romance policial apresenta-se intimamente associada à história do crime, já que sua expansão quantitativa acarreta a transformação qualitativa: "o consequente domínio do crime organizado colocou um ponto final no romance policial ambientado numa sala de visitas" (MANDEL, 1988, p. 62). Deste modo, com a quebra da bolsa de valores de Nova York, no final do segundo decênio, que ocasionou a Grande Depressão, o detetive acostumado a usar unicamente seu intelecto para decifrar os crimes vê-se diante de um grande impasse: 0 desaparecimento das dicotomias ordem $\mathrm{x}$ desordem; legalidade $\mathrm{x}$ ilegalidade; verdade x mentira.

Era a chegada do roman noir ${ }^{4}$ nos Estados Unidos, diretamente relacionado à realidade dos anos de 1930. Um novo público, diferente daquele que aceitava um policial que seguisse os métodos de Dupin ou Holmes, começa a emergir. A evolução do gênero detetivesco tornou os crimes mais 'humanos' e os detetives procuram entender como e por que agem os criminosos, conforme assinala Paulo de Medeiros e Albuquerque: "aqui, juntamente com os crimes, surge a necessidade de se fazer verdadeiros estudos psicológicos, dada a sua origem coincidir com uma época caótica e muitas vezes incompreensível" (ALBUQUERQUE, 1979, p. 106). que vale nesta mudança é a vitória da Inteligência que não deve ser apenas do detetive que resolve o problema, mas também do criminoso ao executar o crime da maneira mais perfeita possível.

\footnotetext{
${ }^{4} \mathrm{O}$ termo roman noir tem sido aplicado à literatura pós-guerra das décadas de 40 e 50, iniciada pela série noire dos romance policiais de Marcel Huhanel.

Porém, o romance americano nasceu na década de 30 e trouxe uma grande evolução no romance policial. As duas figuras mais importantes foram Dashiell Hammet e Raymond Chandler.
} 
Assim é que, com a nova realidade econômica vivenciada pelos Estados Unidos, a partir da quebra da bolsa em 1929, e o consequente caos resultante da dificuldade financeira, presenciamos uma polícia às voltas com a corrupção. Nesta nova modalidade policial, não há ganhadores no jogo da caça ao crime. $\mathrm{O}$ detetive, isolado e em conflito com a polícia, nem conclui seu trabalho com alegria do dever cumprido, nem compartilha do sentimento de acreditar que existe gente competente para lidar com diabólicos velhacos. Por isso, o chamado romance negro, cujo iniciador seria Hammet, acaba sendo adotado por romancistas como Rubem Fonseca ou GarciaRoza,especialmente por situarem o crime num mundo sem valores autênticos e numa sociedade corrompida. Pondo um fim à delicadeza do policial inglês, o detetive particular americano sai a campo, qual um moderno Dom Quixote, a lutar contra a corrupção social e a força das organizações: "Não importa quem matou; é necessário descobrir as razões do crime, que também não são mais individuais, incluindo uma rede intrincada de motivações"
(PELLEGRINI, 1999, p. 92). Quanto ao momento e às condições em que surge, no Brasil, anos de 1980, podese dizer que encontra solo fértil em função da ausência de maiores motivações políticas, e da generalizada descrença em projetos de transformação. Esse descrédito nas instituições e a atitude nostálgica que toma conta do detetive do roman noir estão presentes nas narrativas de Garcia-Roza.

Afinal, o cenário contemporâneo desponta como um ambiente caótico, sombrio, inseguro, onde as relações de controle da máquina estatal fomentam doenças no ser humano. $O$ capitalismo e as falcatruas institucionais pode ser vistos simbolicamente como monstros que geram conflitos, desajustes e instabilidade nos personagens, sobretudo no detetive. Sua impossibilidade de completude ou de desvendar mistérios que lhe aparecem advém do medo e do pavor criados pela violência urbana.A ausência de sistemas coerentes e íntegros provoca deformidades e nostalgias nas personagens contemporâneas, conforme se percebe em Espinosa sem saída. O narrador demonstra que 
a vida de Espinosa se apoia em um equilíbrio instável, a começar pela própria condição de policial no cenário carioca, onde as fronteiras entre mocinho e bandido encontram-se nitidamente abaladas. Consciente de que o inimigo pode estar ao lado de sua mesa, o delegado deposita sua confiança exclusivamente em Welber ou Ramiro, "dois policiais que não aceitavam certos agrados dos comerciantes. Mas exatamente por isso eram talvez os únicos em quem Espinosa confiava sem restrições" Embora Espinosa faça parte de uma corporação, ele age como um private eye (detetive privado): "Continuou andando e pensando no tipo estranho que era. Excêntrico e descentrado em relação à instituição policial" (ESS, p. 81). O delegado realiza seu trabalho isoladamente e, embora na prática não tenha se desligado da unidade de polícia, como os detetives de Hammet ou Chandler, seu agir e métodos já o isolaram há muito.Além disso, a incerteza contamina todas as relações do investigador, que age sozinho e

\footnotetext{
${ }^{5}$ GARCIA-ROZA, Luiz Alfredo. Espinosa sem saída. São Paulo: Companhia das Letras, 2006. p. 23. Todas as citações do romance pertencem a esta edição e serão indicadas pela sigla ESS, seguida do número da página.
}

rechaça uma corrupção que está onipresente. Ao afastar-se de todos, ele tenta manter sua integridade, não sendo, por essa razão, bem visto pelos demais agentes da corporação a que pertence.

Garcia-Roza cria um policial a la noir. ele trabalha na polícia, mas não passa de uma figura solitária, de um private eye que sabe que tudo vai acabar mal. As tramas de $O$ silêncio da chuva ou Espinosa sem saída serão marcadas pela decepção que cada caso the causou; e pelo sentimento de malogro que o domina. As ações de Espinosa são substituídas por monólogos, nos quais o detetive reflete sobre o seu confronto cotidiano com uma cidade agressiva, por onde circulam indivíduos mascarados que não são aquilo que aparentam ser. Isto porque, através de seu protagonista, Garcia-Roza discute uma importante questão: as transformações nas esferas pública e privada, associadas ao crescimento das grandes cidades, são responsáveis pelo individualismo exacerbado e pela solidão do homem contemporâneo.Sendo assim, os romances rozeanos conferem ao leitor sentimento de maior frustração e malestar: Espinosa percorre a trama 
ficcional em busca dos fios significativos, mas não consegue juntá-los. As mortes continuam acontecendo e ele sente-se impotente diante da força do meio que se tornou hostil pela grande concentração de indivíduos e seu relacionamento irracional e desordenado. Em $O$ silêncio da chuva, os espetáculos da vida social se sobrepõem sem que necessariamente possuam coerência entre si, sendo múltiplos, variados. Os cenários são muitos, as possibilidades de leitura e interpretação, quase infinitas. No episódio inicial do romance, as imagens são jogadas para o leitor fragmentadamente: um empresário examina uma arma "com a delicadeza de quem examina uma peça rara" ${ }^{6}$, retira da caixa seis balas. Em seguida, pega o dinheiro do envelope sobre a mesa e coloca-os numa divisão da pasta, separados do revólver. Caminha em direção do edifício-garagem Menezes Cortes. E aí, inicia-se mais um espetáculo da vida social para cujo desfecho não se acha saída: "Entrou no carro, recostou

\footnotetext{
${ }^{6}$ GARCIA-ROZA, Luiz Alfredo. O silêncio da chuva. São Paulo: Companhia das Letras, 2005. p. 126. Todas as citações do romance pertencem a esta edição e serão indicadas pela sigla $S C$, seguida do número da página.
}

a cabeça e ficou pensando nos últimos acontecimentos. Saboreou o cigarro lentamente. Assim que terminou, fechou novamente os vidros, abriu a pasta, retirou o revólver, encostou o cano na têmpora direita e puxou o gatilho" ( $S C$, p. 12).

Ao contemplar a cena do crime, a ideia do labirinto se configura diante das infinitas possibilidades de interpretação dos fatos: "Debruçado na murada da rampa de descida do edifício-garagem" (SC, p. 18), Espinosa tenta reconstruir mentalmente a cena e acaba imaginando várias. O narrador descreve minuciosamente cada uma delas (foram cinco, à principio); mas admite que 0 detetive não se preocupava com o rigor formal dessas construções imaginárias e nem se esforçava para retê-las na memória. Afinal, ele "sabia que inúmeras outras surgiriam no curso da investigação sem que nenhuma conservasse a forma original, deixava fundirem-se umas às outras dando lugar a cenas mais complexas" (SC, p. 19). O curioso é que de todas as construções de Espinosa, nenhuma delas o remete à questão do suicídio: "Uma quinta cena, a do suicídio, não chegou a se 
esboçar. Não fora encontrada nenhuma arma no carro" (SC, p. 19). Um aspecto que aproxima o policial de Garcia-Roza do private eye principalmente de Marlowe $^{7}$ - é a sensação de desconforto oriundo do sofrimento das vítimas. Tal sentimento agrava-se ainda mais pela incapacidade de solucionar assassinatos sem razões aparentes, como o do mendigo Magro em Espinosa sem saída. $O$ delegado apresenta ao leitor seus questionamentos acerca dos motivos que teriam levado o arquiteto (Aldo Bruno) a cometer o crime: "Por que um homem jovem, bonito, rico, bem casado, bem-sucedido profissionalmente, ia colocar tudo isso em risco matando um sem-teto miserável e aparentemente inofensivo?" (ESS, p. 72). A procura sistemática de pessoas e coisas acaba sendo, para ele, um processo de estranhamento e acentua seu caráter

\footnotetext{
${ }^{7}$ Philip Marlowe é um personagem de ficção criado pelo escritor Raymond Chandler para protagonizar uma série de histórias de detetive na linha do roman noir. A estreia do private eye (detetive particular) Marlowe foi em The Big Sleep, publicada em 1939. Contudo, muitas das primeiras histórias de Chandler foram publicadas anos antes e reaproveitadas nos seus romances, com o nome do protagonista original mudado para Philip Marlowe. (MANDEL, Ernest. Delícias do crime. História social do romance policial. São Paulo: Busca Vida, 1988).
}

de perdição diante do olhar dos próprios suspeitos: "O delegado não é a encarnação do demônio. Aparentemente está tão perdido quanto eu no que se refere ao episódio do mendigo" (ESS, p. 120).

Afinal, o medo e o mal, presente desde os primórdios, acentuam-se à medida que as cidades crescem e se urbanizam. Dentre todos os medos, merece destaque o que provém da violência. $O$ crime aparece há muito como o agente causador da desordem e do mal que contamina a civilização. $\mathrm{Na}$ luta entre a ordem e o caos, encontra-se 0 detetive, que está inequivocamente no lado da ordem cultural. Mas, se por um lado, os heróis clássicos ainda podiam contar com a razão, atributo permanente e universal dos seres humanos, para restabelecer a lei e a organização sociais, por outro, no cenário atual, as ferramentas da razão tornam-se impotentes quando se trata de inserir o mal na ordem do inteligível. A humanidade se vê enfrentando males produzidos pelo homem que são tão cruéis, insensíveis, aleatórios e impossíveis de prever: "Os males produzidos por seres humanos parecem agora tão inesperados, 
quanto 0 são os provocados por animais irracionais" (BAUMAN, 2008, p. 86).

No cenário das narrativas policiais atuais, o restabelecimento da ordem e da moral torna-se impossível; e uma das razões é a desintegração da subjetividade contemporânea. Como lidar com a desordem e o caos urbanos, se o detetive não consegue lidar com a desorganização de sua própria interioridade? $\mathrm{Na}$ perspectiva do sociólogo polonês, o mal tende a ser invocado quando insistimos em explicar o inexplicável. De protetor e restaurador da segurança pública e social, o policial passa a constituir uma ameaça e perigo para si e para os outros: "a variedade moderna de insegurança é marcada pelo medo da maleficência humana e dos malfeitores humanos" (BAUMAN, 2008, p. 171). Isto explica, talvez, tanto 0 afastamento de Espinosa de grupos ou categorias específicas de homens e mulheres, quanto a sua recusa em confiar na constância, dedicação e fidelidade dos parceiros humanos. $O$ protagonista de Garcia-Roza experimenta uma frustração de esperanças que se intensifica pelo dano da insegurança e pelo insulto da impotência.; tudo isso canaliza a ansiedade para um desejo de localizar e punir os culpados.

Essa ideia aparece em Espinosa sem saída, na obstinada tentativa de Espinosa de pôr as mãos no assassino de Magro, o mendigo sem perna. Este se converte no maior de todos os mal-estares do personagem: o mundo da ficção, como - da realidade, apresenta-se ao indivíduo como um jogo, ou antes, uma série de jogos aleatórios e indecifráveis. Diante da angustiante complexidade em que se encontra, o delegado não consegue reduzir "o infinito caos da realidade [ficcional] a proporções intelectualmente compreensíveis e evidentemente lógicas" (BAUMAN, 1998, p. 156). A complexidade do mundo, regido pelo jogo do disfarce e da duplicidade faz com que o detetive tenha consciência de que não poderá encontrar a verdade que tanto busca.

Se a palavra da ficção contemporânea é uma palavra impura, isto é, desprovida de autenticidade ou verdade, então o simulacro torna-se o ator principal: "Neste jogo de cena, em que a liberdade está em questão, a representação ficcional funciona como 
- real da representação teatral" (BARBIERI, 2003, p. 21). O mundo inteiro é um palco, levando policiais como Espinosa, perdidos em labirintos, a emergirem como subjetividades que não encontram respostas para os seus questionamentos, e já não compartilham da noção de totalidade do investigador de enigma. Aliás, vale lembrar que os primeiros germes da falibilidade aparecem em um dos grandes detetives clássicos: o lendário Sherlock Holmes. Num conto intitulado "Um escândalo da Boêmia", o detetive falha na aplicação de suas táticas racionais e dedutivas, ao ser ludibriado pela atriz Irene Adler, já que não fora capaz de antecipar-lhe os passos e nem impedir sua fuga. Embora tivesse sido prevenido acerca da mentalidade superior da mulher, Holmes ousou sequer imaginar o fracasso em uma missão:"As mulheres são muito dissimuladas e têm seu próprio modo de guardar segredos" (DOYLE, 1999, p. 24).Seria este o prenúncio de que a Razão e a Verdade absoluta dos fatos não subsistiriam por muito tempo? 0

${ }^{8}$ DOYLE,Arthur Conan. Um escândalo na Boêmia. In: Um estudo em vermelho. [A Study in Scarlet (1887)]. Trad. Antonio Carlos Vilela. São Paulo: Melhoramentos, 1999. fracasso do detetive clássico, que se estende aos heróis noir e aos policiais da atualidade, pode ser explicado através das palavras de Irene Adler: "eu também sou atriz treinada" (DOYLE, 1999, p. 30.

É o mundo de sombras, de dissimulações, de disfarces e ambiguidades, contra o qual o detetive não consegue lutar. desconhecimento da cidade e das pessoas que nela circulam é um dos fatores geradores do mal-estar que atravessa as narrativas policiais desde sua origem: os planos de Holmes foram frustrados pela sagacidade de Irene, a quem ele se refere como "a mulher". Não há dúvida de que a raiz do mal-estar detetivesco aparece na impossibilidade de o "especialista em criminologia" (DOYLE, 1999, p. 23) de adentrar a natureza obscura da personagem. A frustração de Holmes tem a ver com 0 fracasso na realização de um desejo: o detetive não fora capaz de salvar o reino da Boêmia das ameaças da femme fatale. O que constitui uma falha na tarefa de "proteger os homens contra a violência das forças da natureza humana" (FREUD, 1996, p. 96). 
Assim sendo, a ambiguidade torna-se um ingrediente essencial ao universo ficcional (e ao psicanalítico) a partir da recusa do óbvio, do dado, e do construído. São os fragmentos, as peças aparentemente desconexas que conduzem detetive e psicanalista ao trauma velado no inconsciente - razão pela qual fracassam em suas missões. Freud, que dedica a investigar as doenças culturais $e$ as grandes neuroses que perpassam a contemporaneidade, considera que o perfil de uma comunidade interfere diretamente na formação o indivíduo. Então, se o coletivo afeta o subjetivo, "não temos nós justificativa em diagnosticar que, sob influências culturais, algumas civilizações se tornaram neuróticas? " (FREUD, 1996, p. 146). Lidar com uma sociedade neurótica, psicótica e esquizofrênica não se transforma no maior desafio do detetive atual? Maior até do que lidar com o crime propriamente dito?

Os perigos que tememos transcendem nossa capacidade de agir e, em função disso, o sentimento de impotência - o impacto mais assustador do medo - reside, sobretudo, não nas ameaças percebidas ou imaginadas em si, mas "no espaço amplo que se estende entre as ameaças de que emanam os medos e nossas reações" (BAUMAN, 2008, p. 32). O ser humano é dotado de uma espécie de medo de "segundo grau", ou seja, social e culturalmente reciclado que, segundo Bauman, orienta o comportamento humano, quer haja ou não uma ameaça imediatamente presente. Dessa forma, - medo provoca uma sensação de insegurança e vulnerabilidade, tornado as vítimas impotentes no caso de o perigo se concretizar.

No contexto das obras de Garcia-Roza, a geografia da cidade emerge como um ambiente onde a insegurança e o medo tornam-se um assombro que assola a humanidade. $\mathrm{Na}$ era da liquidez, ele apresenta como traço mais opressor a sua abstração e difusão, podendo vir de toda parte e de quem você não é capaz de desconfiar.Desafios e equívocos nosso herói enfrenta em $O$ silêncio da chuva ao investigar a morte de Ricardo Carvalho, diretor executivo da Planalto Minerações. Acreditando o tempo todo tratar-se de um crime, Espinosa engendra-se no labirinto investigativo que se constrói no entorno deste empresário. A começar pela 
perseguição de suspeitos como Max e Rose: Espinosa desloca-se de um ponto a outro da cidade carioca, na tentativa de encontrá-los, já que são indispensáveis para a elucidação do caso do empresário. Mas os dois convertem-se em fantasmas, de modo que a ambiguidade se mantém até 0 fim da aventura: "realidade ou sonho? Verdade ou ilusão? (TODOROV, 1970, p. 30). Os fantasmas que 'assombram' os personagens das narrativas fantásticas e conferem à história a atmosfera de ambiguidade, figuram, mesmo que de forma distinta, como a pedra de tropeço para que Espinosa chegue à resolução e à verdade dos fatos.

A perda de referencial e os enganos do policial são flagrados em vários momentos no livro. Primeiramente, por deixar de levantar a hipótese de suicídio (que foi o que acontecera a Ricardo) e por nunca cogitar a hipótese de ser o amigo Aurélio (ex-policial) um criminoso em potencial. Em $O$ silêncio da chuva, onde a relativização de papéis também se torna patente, o detetive também se perde em meio às pistas falsas, deixando-se envolver pelo discurso mentiroso do ex-colega de profissão.
Outra questão que tangencia a ficção policial atual é 0 fato de representantes da lei se deixarem levar pela corrupção e pela ganância grandes motivadores do crime: "We know that the police are not invariably more virtuous and honest than the society from which are recruited, and that corruption can stalk the corridors of Power and lie at the very heart of government and the criminal justice system" (JAMES, 2009, p. 157) ${ }^{9}$.

A corrupção a que James se refere motivou Aurélio a sequestrar a secretária de Ricardo, mantida em cativeiro durante longo período. Tudo no intuito de tomar posse de uma enorme quantia deixada pelo empresário. A dificuldade maior de Espinosa de 'enxergar' o verdadeiro criminoso teria a ver com a crença de que "a função da polícia" é capturar os desviantes - não podendo, por isso, um ex-colega de profissão ser visto como suspeito? A não percepção da 'verdadeira identidade do amigo está ligada à dificuldade do detetive em lidar com enfermidades psíquicas, tais

\footnotetext{
${ }^{9}$ Sabemos que a polícia não é invariavelmente mais virtuosa do que a sociedade a que pertence e que a corrupção passeia pelos corredores do poder e da mentira, e no seio do governo e do sistema judicial criminal.
} 
como as que atravessam Aurélio psicopata em potencial. As fendas aparecem no romance pela falta de argúcia de Espinosa em perceber que o amigo era o culpado, o que reconhece após ter ignorado detalhes escondidos pelo esquecimento: 0 próprio Espinosa fornecera informações do caso a Aurélio, em almoços que este marcava com tanta insistência: "A experiência do expolicial, investigador da companhia de seguros fazia de Aurélio o suspeito óbvio... e tão impossível” (SC, p.241). Parece-nos que o investigador se esquece de algo importante no cenário da pós-modernidade: "como pode uma cultura supostamente definida pelo abandono decisivo da originalidade e da autencidade ser exemplificada de forma 'original' ou autêntica'? (CONNOR, 1992, p. 47).

Aprender a lidar com as 'monstruosidades' contemporâneas (medos, traumas, psicoses, neuroses) torna-se 0 desafio do policial de Garcia-Roza a todo instante em Espinosa sem saída. O assassinato de Magro (o sem-teto) ocorre num culde-sac sombrio, em plena madrugada de chuva - corroborando a ideia de que a escuridão não constitui a causa do perigo, mas é o habitat natural da incerteza e, portanto, do medo.Este é o sentimento que acomete Aldo Bruno (o autor do crime), que oscila entre a alternativa da fuga ou da agressão. Após a experiência traumática da infância, 0 arquiteto atravessa a adolescência fugindo do malfeitor (Nilson). Já adulto, assassina o mendigo, acreditando extirpar a figura do mal (simbolizado pelo agressor ou malfeitor), como ele declara a Espinosa no final: "_Eu não o matei! Ele me matou!" (ESS, p. 206). Neste sentido, o réu não deve ser classificado como criminoso, mas como pessoa "doente, psicopata ou sociopata, devendo ser submetido a tratamento psiquiátrico, e não à prisão ou forca" (BAUMAN, 2008, p. 82). A dificuldade do detetive advém destes males produzidos por seres humanos que parecem, agora, tão inesperados. Para compreendê-los, é necessário que os fatos sejam vistos em retrospecto, fato que exige destes profissionais a capacidade de adentrar camadas profundas do inconsciente dos 'criminosos'.Como um detetive 'psicanalista', Espinosa descobre que o arquiteto assassinara, também, a doutora Camila Bruno, em função de 
atos promíscuos. O comportamento "degradante da esposa", que aparece transformada numa pessoa sexualmente perversa, poderia facilmente se tornar público - o que atingiria a honra dos filhos, daí a atitude do homem de "colocar um ponto final na história" (ESS, p. 207). Todos os personagens que cruzam o caminho do policial são atravessados por uma série de enfermidades psíquicas, reforçando a ideia de que pensamentos e comportamentos humanos não podem ser explicados de forma racional (FREUD, 1996, p. 138). Não é aleatório, então, o fato de seus personagens viverem em constantes dúvidas e incertezas, haja vista que eles compõem um universo simulado, onde se apaga a diferença entre original e cópia, verdadeiro ou falso.

No romance, Espinosa chega à conclusão de que a opção mais óbvia para Aldo era matar a esposa de modo que o crime parecesse obra de "algum maníaco sexual...um psicótico... um psicopata... um tipo bem distante da imagem que a socialite passava para as pessoas. Ao criarem para si um lugar imaginário, as singularidades de Espinosa sem saída perdem cada vez mais a noção de referência: "esses lugares de fantasia são sempre duplos", pois oscilam entre a realidade e a representação, entre o que são e o que pretendem ser" (PEIXOTO, 1987, p. 207). Eis o grande dilema contemporâneo na visão do crítico da cultura: a descrença na verdade, na razão, na objetividade e na lógica. No cenário das narrativas atuais, tais valores dão lugar ao simulacro, à duplicidade, que direta ou indiretamente, atingem todos os personagens envolvidos nos casos de que cuida Espinosa. Camila Bruno, por exemplo, praticava algumas excentricidades em sua prática clínica, a começar por manter relações sexuais com algumas pacientes. Uma delas, Antônia, aliás, Mercedes, esconde da terapeuta 0 fato de trabalhar com Aldo - que mais tarde se torna, também, seu amante. $O$ jogo de falsidade e simulação chega ao fim quando 0 detetive desmascara a arquiteta e exige-lhe esclarecimentos referentes à identidade: Mercedes, Antônia, Maria Antônia? No entanto, surpresa maior recebe 0 parceiro quando 0 delegado the revela a "múltipla identidade da doutora Mercedes e das diferentes 
personalidades que elas representam" (ESS, p. 199).

A questão da identidade e do relativismo de papéis configura-se na trama como indício de que a psicanálise convoca a todos como sujeitos trágicos (PIGLIA, 2004, p. 52) - e que ninguém é apenas bom ou mau. Acrescenta-se a isso 0 apagamento que se faz entre as noções de verdade e mentira, que fica claro no relato de Mercedes: "Não há mentira na prática psicanalítica", assim como não há verdade absoluta (ou definitiva) nos relatos daqueles envolvidos nos crimes. A plena consciência do policial do quão fugidia se torna a verdade manifesta-se quando Mercedes confessa que a troca de nome não fora feita com o intuito de matar a doutora Camila: "é um raciocínio pobre. Ele matou sozinho a doutora Camila. Eu a amava. Nós nos amávamos" (ESS, p. 200). Isso nos dá margem a seguintes reflexões: não são os equívocos de Espinosa frutos da própria relação entre 0 discurso policial e 0 psicanalítico?

Tendo que lidar com as neuroses, psicoses, psicopatias, traumas, medos - esses grandes 'monstros' da cultura contemporânea o detetive se sente capaz de vencêlos? Afinal, era preciso que Espinosa fosse um detetive da alma para que obtivesse o êxito esperado. Se nem mesmo Freud, que tem a cooperação do analisado, se propõe a ser um 'detetive da alma', como o personagem de Garcia-Roza o conseguiria sem a cooperação do 'suspeito'? Para descobrir os crimes contra Magro (sem-teto) e contra a esposa, o delegado precisaria alcançar o recôndito, o traumático, o fobíaco e o doentio do interior do arquiteto, da amante e da psicanalista. O homem é marcado por traumas de infância e acometido de sintomas psiconeuróticos: daí a manifestação da pulsão da crueldade em suas formas passiva e ativa e domina quase invariavelmente a conduta social do doente: "Por intermédio dessa ligação da libido com a crueldade que se dá a transformação do amor em ódio, das moções afetuosas em hostis, que é característica de um grande número de casos de neurose e até, ao que parece, da paranoia em geral" (FREUD, 2002, p. 44). Sendo assim, nos romances de Garcia-Roza, a violência e o crime são motivados por 
subjetividades atingidas por diferentes enfermidades comportamentais, desajustadas, cujo esvaziamento tem a ver com o fim do ego burguês ou do descentramento do próprio sujeito - 0 qual acarreta, ainda, no esmaecimento do afeto no contexto atual. Muitas das qualidades de vida no capitalismo tardio têm seu eco no âmbito cultural, num novo fascínio pela confusão, pela desintegração da subjetividade, pelo que

Jameson resume como uma espécie de esquizofrenia - não no sentido meramente clínico ou com propósitos diagnosticais. Seguindo a concepção lacaniana que descreve a esquizofrenia como sendo a ruptura na cadeia dos significantes (JAMESON, 1997, p. 53), Jameson considera que o indivíduo perde gradativamente a capacidade de organizar seu passado e futuro como uma experiência coerente; principalmente porque está imerso numa cultura cada vez mais dominada pela lógica espacial. Por isso, torna-se bastante difícil perceber como a produção cultural de tal sujeito poderia resultar em outra coisa que não "um amontoado de fragmentos" que apontam para um comportamento 'esquizofrênico'. Este nada mais é do que consequência do mal-estar que toma conta do indivíduo dominado pelo medo e pela insegurança diante da violência e da desordem social.

A subjetividade, como explica Félix Guattari (1993), não é passível de totalização ou de centralização no indivíduo. Já de início, o autor esclarece que a subjetividade não implica uma posse, mas uma produção incessante que acontece a partir dos encontros que vivemos com o outro. Nesse caso, o outro pode ser compreendido como o outro social, mas também como a natureza, os acontecimentos, as invenções, enfim, aquilo que produz efeitos nos corpos e nas maneiras de viver. Tais efeitos difundem-se por meio de múltiplos componentes de subjetividade que estão em circulação no campo social: "a subjetividade é essencialmente fabricada e modelada no registro do social" (GUATTARI, 1993, p.178).As reflexões de Guattari tornam-se relevantes no processo de construção das subjetividades criminais de GarciaRoza. Primeiramente, porque suas tramas se organizam em torno da morte, que, sob o olhar da psicanálise, constitui um ato de rompimento e/ou desvio definitivo dos parâmetros da lei. 
Por isso, os estudos de Freud sobre 0 inconsciente auxiliam, também, na compreensão da subjetividade criminal contemporânea. A começar pela dificuldade de se distinguir a natureza dos homens, sempre ligada a esse Outro regido por instintos primitivos - daí a identificação de suas ações com o caos, com o mistério e com o ilógico (FREUD, 1996, p. 347). O que a psicanálise reconhece como crimes ou delitos provenientes da censura inconsciente são aqueles cujas condutas tornam-se claras à luz da interpretação edipiana. Mas o que as distingue como mórbidas é o seu caráter simbólico. Sua estrutura psicopatológica não está na situação criminal que elas exprimem, mas no modo irreal dessa expressão: "as estruturas da sociedade são simbólicas. O indivíduo, na medida em que é normal, serve-se delas em condutas reais; na medida em que é psicopata, exprime-as por condutas simbólicas" (LACAN, 1998, p. 134).

Não é este o caso de Aurélio, cuja conduta imaginária permite a sua adaptação parcial ao real? Se o supereu, enquanto manifestação individual, está ligado às condições sociais do edipianismo, as tensões criminosas se instauram e se tornam patogênicas nas sociedades quando essa própria situação se desintegra. Por isso, homem e animal se igualam na violação da lei de castração e na busca incessante de realização dos desejos - 'instintivos', 'primitivos' ou 'animalescos'. Acerca desta ideia, Bataille explica que as proibições passaram a separar o animal do homem, sendo este o único a observálas. Para a humanidade primitiva, 0 animal não podia ignorar uma lei fundamental: que 0 seu próprio movimento, a sua própria violência era uma violação da lei. "Em comparação com uma vida calculada, morte e violência são delírio, pois que nem o respeito nem a lei, que socialmente ordenam a vida humana, as podem deter" (BATAILLE, 1980, p. 74). A morte, para uma consciência ingênua, só pode vir duma ofensa, duma falha que mais uma vez, destroem violentamente a ordem legal. O crime, porém, configura-se de forma distinta nos romances. Em Espinosa sem saída, ele foi proveniente do trauma sofrido pelo arquiteto ainda criança. Agredido por um menino de rua (Nilson), cujas ações foram regidas pelas mesmas leis da selva primitiva, 0 


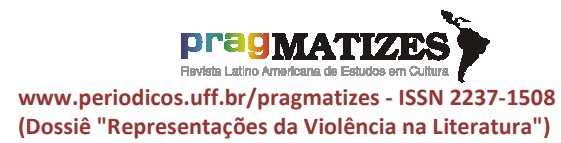

sujeito ficcional submete-se à castração pelo negar-se de si próprio.

Se os impulsos humanos devem ser domados em impulsos de meta inibida, ou seja, anestesiados, o personagem incorpora as grades do decoro social em seu corpo e mente. Mas o regresso ao que primeiramente havia negado acontece em função das experiências traumáticas infantis, provenientes de conflitos reais com 0 mundo externo. Sandor Ferenczi (1992) considera que a reação imediata ao trauma é uma comoção, uma agonia psíquica e física que acarreta uma dor incompreensível e insuportável. A dor é tão extrema que a criança precisa distanciar-se de si mesma, afastar-se de seu psiquismo e de seu corpo. As descrições de Ferenczi em relação à comoção psíquica aludem sempre ao terror, à catástrofe, à morte. $\mathrm{O}$ desprazer causado pela comoção é tão superlativo que não pode ser superado, exigindo uma válvula de escape: "Tal possibilidade é oferecida pela autodestruição, a qual, enquanto fator que liberta da angústia, será preferida ao sofrimento mudo" (FERENCZI, 1992, p. 111).
Nasce, assim, a desorientação psíquica que, se por um lado destrói a consciência, por outro ajuda a suportar a dor moral. A subjetividade, enquanto processo de produção no qual comparecem e participam múltiplos componentes, é produto de uma heterogeneidade de elementos presentes no contexto social. Assim, valores, ideias e sentidos ganham um registro singular, tornando-se matériaprima para expressão dos afetos vividos nesses encontros. Essa produção de subjetividades, da qual o sujeito é um efeito provisório, mantémse em aberto uma vez que cada um, ao mesmo tempo em que acolhe os componentes de subjetivação em circulação, também os emite, fazendo dessas trocas uma construção coletiva viva. Assim, esses componentes ganham importância coletiva e são atualizados de diferentes maneiras no cotidiano de cada vivente. A angústia, que parece constituir a humanidade mesmo aquela ultrapassada - destrói - caráter de passividade do personagem (Aldo) que após situação traumática acaba por se converter numa subjetividade criminal.

No universo da ficção, o assassino aparece como um neurótico 
que procura neutralizar a dor e 0 sofrimento decorrentes das experiências traumáticas infantis. Entretanto, o desprazer cresce e exige uma válvula de escape, oferecida pela destruição de si e dos outros. Numa posição extrema, como a de ameaças, medos, e perigos, o personagem passa a desejar aquilo que faz perigar a sua vida. Se o perigo é demasiado pesado, se a morte é inevitável, em princípio, o desejo fica inibido. Contudo, se a sorte nos auxilia, "o aspecto que mais ardentemente desejamos é o mais susceptível de nos arrastar para gastos loucos e de nos arruinar" (BATAILLE, 1980, p. 77). A sorte de que fala o estudioso atravessa o caminho do arquiteto na ladeira da infância de Espinosa. No ápice do delírio, o rapaz 'instintivamente' atira à queima-roupa, a fim de eliminar definitivamente 0 agressor. Como assinala Nietzsche, se o ressentimento é em si o que está proibido aos doentes, - o seu mal infelizmente é, também, a sua tendência mais primitiva e natural.

Relacionado a um problema fisiológico, o ressentimento serve para evidenciar aquele homem sem forças para reagir diante dos imprevistos e das dificuldades da vida e que, também, não consegue digerir os maus

sentimentos, aqueles sentimentos nocivos, venenosos, produzidos por sua incapacidade de realizar a verdadeira reação, a dos atos. Dessa forma, esse indivíduo passa a manifestar um desequilíbrio psicológico que o impossibilita de viver de forma espontânea, ativa;e movido por "uma vingança imaginaria", passa a viver em função de "um 'fora', um 'outro', um'não-eu', próprio do ressentimento. A compreensão de sua própria fraqueza e o sentimento de decepção em decorrência da impossibilidade da ação gera um rancor, uma vontade de ferir e magoar aquele que o desprezou. Assim, surge nele um desejo de vingança que a sua covardia o impossibilita de realizar, a não ser de um modo falso e inventivo,uma vez que o homem do ressentimento é afeito a atitudes suspeitas e evasivas.

O homem do ressentimento não é franco,nem ingênuo, nem honesto e reto consigo. Ele ama os refúgios, os subterfúgios, os caminhos ocultos, tudo escondido Ihe agrada como seu mundo, sua segurança, seu bálsamo; ele entende do silêncio, do não 
esquecimento,da espera, do momentâneo, e da humilhação própria (NIETZSCHE, 1998, p. 22). O personagem de Garcia-Roza é esse sujeito ressentido, cujo desejo de vingança foi capaz de transpor qualquer covardia ou lei. As vivências o afetam com demasiada profundidade, e as recordações tornam-se feridas tão purulentas que ele parte para 0 caráter de autodestruição. $\quad \mathrm{c}$ crime por transferência transforma 0 personagem de Garcia-Roza num criminoso, e dá-lhe o poder de aplicar ao malfeitor o castigo merecido característica essencial da ideia do homem que prevalece numa dada sociedade.

Os impulsos criminosos advêm da desordem das categorias sociais, e só são apreensíveis no estado psicopático em que se instaura 0 indivíduo. Por outro lado, permite-lhe ir ao encontro do 'gozo' impossível, descrito por Lacan como a alucinação fundamental: "se todos os homens, ou melhor, os neuróticos, vivem constantemente alucinados, poderiam ser considerados como loucos e se aproximam dos psicóticos, uma vez que ambos se sustentam de uma projeção imaginária" (WILLEMART, 1995, p. 19). Na trama de Espinosa sem saída, Aldo tenta suprimir os males sociais através da neutralização da agressividade - mandada de volta à origem e dirigida contra o próprio eu. A cultura humana, aquela em que a vida humana se elevou acima de suas condições animais e distinta da vida dos bichos, abrange, por um lado, todo o saber e capacidade adquiridos pelo homem com o fim de dominar as forças da natureza; por outro, todas as instituições necessárias para regular as relações e ações dos homens entre si e, em especial, a divisão dos bens acessíveis.Entretanto, como a subjetividade criminal é regida por uma mente infantil primária, ela viola as intermediações do superego e cede à satisfação dos impulsos. Por isso, precisa ser punido pelo fato de ter burlado a lei, o controle representado pelo Pai - e deve ser punido pela sociedade. No plano da ficção, Espinosa - metáfora da ordem e do cumprimento da lei - precisa lidar com mais um assassinato - o da esposa do arquiteto.

Se o primeiro crime realizado pelo homem justifica-se, de certa forma, pelas angústias decorrentes do 
trauma, o segundo pode ser entendido como um desejo de vingança (punição) pelo agir frio e degradante de Camila. Na trama do romance, ela não escapa do perfil de um criminoso ao violar a moral e ordem instituídas. Ao se transformar "numa pessoa sexualmente perversa, com um comportamento que poderia facilmente se tornar público" (ES, p. 206), a mulher não deixa de ameaçar a imagem da família, daí a responsabilidade do personagem marido e pai - de aplicar o castigo oriundo do ato de transgressão. De acordo com Lacan, o crime torna o indivíduo um foracluído, mas ao mesmo tempo permite-lhe experimentar um poder perdido - o da sua castração como ser, lá quando era criança (LACAN, 1998, p. 139). Ser juiz e decidir sobre a vida ou a morte de outros não seria uma forma de o criminoso reverter sua castração?

O poder de matar ou de poupar a vida da esposa não se torna a prova maior da filiação do personagem à categoria criminal? E se a lei moral se afirma contra a satisfação dos impulsos e do prazer, é preciso pagar com alguma coisa: "essa alguma coisa se chama gozo, o bem que se paga pela satisfação do desejo" (LACAN, 1997, p. 386). No sentido psicanalítico, a sexualidade humana, no fundo, pode ser definida como 'perversa', na medida em que nunca se desliga inteiramente das suas origens, que a fazem procurar sua satisfação não numa atividade especifica, mas no ganho do prazer ligado a funções ou atividades que dependem de outras pulsões (FREUD, 2002, p. 45). O criminoso deseja reverter sua castração pelo poder de ameaça que ele representa. Se a lei moral se afirma contra o prazer, a morte de Camila significa a punição do indivíduo que faz dos instintos a lei natural da realização dos desejos? Ou a libertação plena de uma sociedade castradora, incapaz de saciar os desejos de qualquer sujeito? Se atentarmos para este significado, a morte pode ser vista como auge, o fim da angústia de alguém cuja vivência não passa de um evento de ficção. Freud sustenta que o indivíduo é virtualmente inimigo da civilização, visto o pesado fardo dos sacrifícios impostos pelos poderes coercitivos aos impulsos e aos desejos naturais.

Freud aponta que é através do sentimento de culpa que a civilização 
impede que a potência dos instintos se transforme em ato. Se a culpa atormenta 0 arquiteto de Espinosa sem saída, ela não se torna aparente nas violações morais e criminosas praticadas por Aurélio, em $O$ silêncio da chuva. Aqui, os processos de singularização apontados por Guattari podem ser entendidos como algo que frustra esses mecanismos de interiorização dos valores capitalísticos, e que pode conduzir à afirmação de valores num registro particular, independentemente das escalas de valor que nos cercam e espreitam por todos os lados (GUATTARI \& ROLNIK, 1996, p. 47). No romance de estreia de GarciaRoza, a coerção que o indivíduo sofre pelo sistema social maquínico, atrelado ao seu desejo de ambição, transforma-o num criminoso, e demonstram a sua foraclusão ou assujeitamento diante da ordem vigente.

No caso de Aurélio, a tensão entre o severo superego e o ego não consegue dominar 0 seu perigoso desejo de agressão, "enfraquecendoo, desarmando-o e estabelecendo no seu interior um agente para cuidar dele, como uma guarnição numa cidade conquistada" (NIETZSCHE, 1998, p. 19). Assim, se em Freud a restrição aos impulsos produzirá sentimento de culpa, em Nietzsche o sentimento provocado pela repressão aos desejos naturais do homem, o não-gozar da liberdade experimentada no estado de natureza, gera ressentimento. A civilização, nas proposições nietzschiana e freudiana, se constitui como cultura inumana de recalque dos desejos, sendo o malestar e a angústia os efeitos do excesso das restrições impostas pelas agências moralizadoras. Neste sentido, além de ser uma forma de expelir aquilo que nos fere, o crime em O silêncio da chuva pode ser visto como uma prática libertadora e de extremo prazer. Agindo como se não fosse viver o amanhã, Aurélio segue lado a lado com Espinosa, sem ao menos sentir medo da punição. Para Freud, estes são os criminosos adultos que praticam crimes sem qualquer sentimento de culpa; que, ou não desenvolveram quaisquer inibições morais, ou, em seu conflito com a sociedade, consideram sua ação justificada (FREUD, 1996, p. 348).

Tais ações são típicas de delinquentes psicopatas ou sociopatas 
cujo crime corresponde ao de um perverso agindo friamente lembremos que todas as mortes provocadas por Aurélio no romance exploram a violência por mutilação. Daí a dificuldade de Espinosa na captura deste tipo de desviante: "Não há retrato que corresponda ao perverso. Pode parecer com qualquer um de nós" (SC, p. 125). O agir do personagem - metaforizando o agir de qualquer sujeito de nossa realidade estaria relacionado à satisfação do prazer aniquilado pela cultura. E se a lei moral se afirma contra a satisfação dos impulsos e do prazer, é preciso pagar com alguma coisa: "essa alguma coisa se chama gozo, o bem que se paga pela satisfação do desejo" (LACAN, 1997, p. 386).

\section{Problematizando}

vários aspectos da chamada sociedade de massa, de consumo, e acompanhando a desordem provocada pelos impactos de um mundo globalizado, capitalista e perigoso, a trama policial de GarciaRoza, um dos maiores escritores da América Latina, apresentam personagens que se constroem sob o signo do simulacro.Isto quer dizer que a realidade que seus livros representam é mascarada, fingida ou representada - algo que condiz com a condição contemporânea: "A forma pós-moderna de ocultamento consiste em obscurecer ou apagar inteiramente a distinção entre verdade e falsidade dentro dos próprios seres" (BAUMAN, 1998, p. 158). Ao detetive que vivencia, ficcionalmente, esta realidade, lidar com uma sociedade sem rosto torna-se o maior de todos os entraves para a reconstituição da moral e da ordem.

A literatura, enquanto a expressão da cultura, caminha de braços dados com as mudanças na ordem social, política e econômica de seus respectivos países. Nesta nova ordem social, crime e criminoso são os verdadeiros componentes dessa barbárie pós-moderna - e neste contexto, a polícia não cumpre a função para a qual fora criada; principalmente pela presença desse Outro, regido única e exclusivamente pelas forças do inconsciente, que são, acima de tudo, inexplicáveis, irreveláveis e inescrutáveis.

\section{Referências bibliográficas}

ALBUQUERQUE, Paulo de Medeiros e. O mundo emocionante do romance policial. Rio de Janeiro: Francisco Alves, 1979. 
BARBIERI, Therezinha. Ficção impura: prosa brasileira dos anos 70, 80 e 90. Rio de Janeiro: EdUERJ, 2003.

BATAILLE, Georges. O crime e o sacrifício. In: O erotismo: o proibido e o transgressor. 2. Ed. Lisboa: Moraes Editores, 1980. p. 73-79.

BAUMAN, Zygmunt. Amor líquido: sobre a fragilidade dos laços humanos. Trad. Trad. Carlos Alberto Medeiros. Rio de Janeiro: Zahar, 2004.

BAUMAN, Zygmunt. Medo líquido. Trad. Carlos Alberto Medeiros. Rio de Janeiro: Zahar, 2008.

BORGES, Jorge Luis. O conto policial. In: Borges oral. Trad. Rafael Gomes Filipe. Lisboa: Veja, 1997. p. 63-74.

CONNOR, Steven. Cultura pósmoderna: introdução às teorias do contemporâneo. Trad. Adail Ubirajara Sobral \& Maria Stela Gonçalves. São Paulo: Edições Loyola, 1992.

DOYLE, Arthur Conan. Um estudo em vermelho. Trad. Antonio Carlos Vilela. São Paulo: Melhoramentos, 1999.

FERENCZI, Sandor. A psicanálise do crime. In: Obras completas: psicanálise II. Trad. Álvaro Cabral. São Paulo: Martins Fontes, 1992. p. 1-10.

FOUCAULT, Michel. $A$ ordem do discurso. 10. ed. Trad. Laura Fraga de Almeida Sampaio. São Paulo: Loyola, 2004.

FREUD, Sigmund. O futuro de uma ilusão, o Mal-estar na civilização e outros trabalhos. Trad. Jayme Salomão. Rio de Janeiro: Imago, 1996 [1929] vol - XXI.

FREUD, Sigmund. O mal-estar na cultura. Trad. Renato Zwick. Porto Alegre: L\&PM, 2010.

FREUD, Sigmund. Três ensaios sobre a teoria da sexualidade. Trad. Paulo
Dias Corrêa. Rio de Janeiro: Imago, 2002.

GARCIA-ROZA, Luiz Alfredo. Espinosa sem saída. São Paulo: Companhia das Letras, 2006.

GARCIA-ROZA, Luiz Alfredo. O silêncio da chuva. São Paulo: Companhia das Letras, 2005.

GROSSI PORTO, Maria Stela. Entre a política e a religião: caminhos da contribuição weberiana à análise da violência. Revista Sociologias, Porto Alegre, PPG-Sociologia do IFCH UFRGS, Número 1, setembro de 1999, Dossiê "Conflitualidades", p. 14-33.

GUATTARI, Félix. Da produção de subjetividade. In: PARENTE, André (org.). Imagem-máquina, a era das tecnologias do virtual. Trad. Rogério Luz et alii. Rio de Janeiro: Ed. 34, 1993. p. $177-191$.

GUATTARI, Félix; ROLNIK, Suely. Micropolítica: cartografia do desejo. Petrópolis, RJ: Vozes, 1996.

ISER, Wolfgang. Epílogo. In: O fictício e o imaginário: perspectivas de uma antropologia literária. Trad. Johannes Kretschemer. Rio de Janeiro: EdUerj, 1996. p. 341-361

JAMES. Phyllis Doroth. Talking about detective fiction. Oxford: Bodleian Library, 2009.

JAMESON, Fredric. A lógica cultural do capitalismo tardio. In: Pósmodernismo: a lógica cultural do capitalismo tardio. Trad. Maria Elisa Cevasco. São Paulo: Ática. 1997. p.27-79.

LACAN, Jacques. O seminário sobre "a carta roubada". In: Escritos. Trad. Vera Ribeiro. Rio de Janeiro: Jorge Zahar, 1998. p.13-66. 
LACAN, Jacques. O seminário. Livro 7: a ética da psicanálise. Trad. Antônio Quinet. Rio de Janeiro: Jorge Zahar, 1997.

MANDEL, Ernest. Delícias do crime: história social do romance policial. Trad. Nilton Goldmann. São Paulo: Busca Vida, 1988.

NIETZSCHE, Friedrich. Segunda dissertação: "culpa", "má consciência" e coisas afins. In: Genealogia da moral: uma polêmica. Trad. Paulo César de Souza. São Paulo: Companhia das Letras, 1998. p.47-85.

PEIXOTO, Nelson Brissac. Cenários em ruínas: a realidade imaginária contemporânea. São Paulo: Brasiliense, 1987.

PELLEGRINI, Tânia. Gêneros em mutação. In: $A$ imagem e a letra. Campinas: Fapesp, 1999. p. 79-240.

PIGLIA, Ricardo. Os sujeitos trágicos. In: Formas breves. São Paulo: Companhia das Letras, 2004.

PIGLIA, Ricardo. Sobre o gênero policial. In: O laboratório do escritor. Trad. Josely Vianna Baptista. São Paulo: Iluminuras, 1994.

POE, Edgar Allan. Histórias extraordinárias. Trad. Breno Silveira e outros. São Paulo: Abril Cultural, 1978.

TODOROV, Tzvetan. Introdução à literatura fantástica. São Paulo: Perspectiva: 1975. [1970]

TODOROV, Tzvetan. O discurso psicótico. In: Os gêneros do discurso. São Paulo: Martins Fontes, 1980.

TODOROV, Tzvetan. Tipologia do romance policial. In: Poética da prosa. Lisboa: Edições 70, 1979. p. 57-67.

WILLEMART, Philippe. A força do inconsciente na literatura e na criação literária. In: Além da psicanálise: a literatura e as artes. São Paulo: FAPESP, 1995. p. 63-105. 